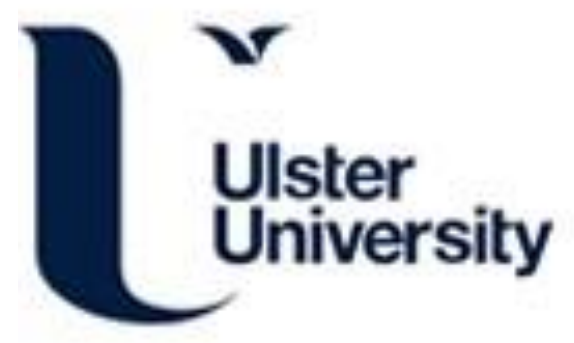

\title{
Truth-justice-reparations interaction effects in transitional justice practice: The case of the 'Valech Commission' in Chile
}

Collins, C. (2016). Truth-justice-reparations interaction effects in transitional justice practice: The case of the 'Valech Commission' in Chile. Journal of Latin American Studies, 49(1), 55-82. https://doi.org/10.1017/S0022216X16001437

Link to publication record in Ulster University Research Portal

Published in:

Journal of Latin American Studies

Publication Status:

Published online: 30/08/2016

DOI:

10.1017/S0022216X16001437

\section{Document Version}

Author Accepted version

\section{General rights}

Copyright for the publications made accessible via Ulster University's Research Portal is retained by the author(s) and / or other copyright owners and it is a condition of accessing these publications that users recognise and abide by the legal requirements associated with these rights.

\section{Take down policy}

The Research Portal is Ulster University's institutional repository that provides access to Ulster's research outputs. Every effort has been made to ensure that content in the Research Portal does not infringe any person's rights, or applicable UK laws. If you discover content in the Research Portal that you believe breaches copyright or violates any law, please contact pure-support@ulster.ac.uk. 
Truth-justice-reparations interaction effects in transitional justice practice: The case of the 'Valech Commission' in Chile

[AUTHOR'S COPY - LATER ACCEPTED FOR PUBLICATION BY THE JOURNAL OF LATIN AMERICAN STUDIES (2016)]

Abstract

Recent thinking and practice in transitional justice suggest that victims and societies hold indivisible, perhaps even simultaneous, rights to truth, justice and reparations after gross human rights violations. This paper analyses the advantages and drawbacks of such holistic approaches to transitional justice, through a case study of Chile's second official truth commission, the 'Valech Commission'. The paper illustrates the politics of ongoing contestation about authoritarian era crimes in Latin America, showing how and why the commission was designed to deliver on certain truth and reparations obligations toward survivors of past state repression, while attempting to explicitly decouple truth revelations from judicial consequences. It also discusses the implications of associating truthtelling and reparations in a single instance, and in doing so contributes to debate about the potentially contradictory or counterproductive outcomes that may arise from the yoking together of truth, justice and reparations functions in transitional justice policy design.

$\underline{\text { Introduction }}$

Since at least the 1980s, and based in large part on experiences from Latin America, thinking and practice about how to manage the legacy of past authoritarian violence and/or massive human rights violations has taken place under the rubric of 'transitional justice.' ${ }^{1}$ Early models of

\footnotetext{
${ }^{1}$ Ruti Teitel, 'Transitional Justice Genealogy', Harvard Human Rights Journal 16 (2003), pp. 69-94.
} 
transitional justice (TJ) practice tended to address truth, justice and reparations questions separately, or even sequentially, crafting dedicated, time-limited instances including truth commissions, prosecutions and/or amnesty laws, and reparations packages for the most directly affected victims. Modern transitional justice thinking seems to be moving away from this modular, 'mix and match' approach, due in part to the migration of the transitional justice paradigm to postconflict settings, and also to growing appreciation of the broad and lasting legacies, including intergenerational legacies, of political violence. Recent studies have investigated the broader and longer societal impact of sui generis inventions such as the truth commission, ${ }^{2}$ and/or the effects of timing and sequencing on anticipated and unanticipated outcomes of TJ policies. ${ }^{3}$ Other theorists have suggested that gender justice, development agendas, and other questions of structural fairness should become part of the transitional justice canon. ${ }^{4}$ At a minimum, international organisations increasingly adopt rights-based and victim-centred framings which speak of simultaneous and complementary right(s) to truth, justice, reparations and (sometimes) guarantees of non-repetition in the aftermath of serious political violence. They derive corresponding matrices of duties incumbent on states, and criticise as deficient measures that address only a single TJ problem or need. ${ }^{5}$

\footnotetext{
${ }^{2}$ Eric Wiebelhaus-Brahm, Truth Commissions and Transitional Societies (New York: Routledge, 2010); Onur Bakiner, 'Truth Commission Impact: An Assessment of How Commissions Influence Politics and Society', International Journal of Transitional Justice, 8:1 (2014), pp. 6-30. For a study of Chile's first truth commission, see Anita Ferrara, Assessing the Long Term Impact of Truth Commissions (Abingdon: Routledge, 2014).

${ }^{3}$ See for example Tricia Olsen, Leigh Payne, and Andrew Reiter, Transitional Justice in Balance (Washington: USIP, 2011.)

${ }^{4}$ Inter alia, Paul Gready and Simon Robins, 'From Transitional to Transformative Justice: A New Agenda for Practice 'International Journal of Transitional Justice 8:3 (2014), pp. 339-61; Dustin N. Sharp 'Emancipating Transitional Justice from the Bonds of the Paradigmatic Transition', International Journal of Transitional Justice 9:1 (2015), pp. 150-69; Lars Waldorf, 'Anticipating the Past: Transitional Justice and Socio-Economic Wrongs'. Social \& Legal Studies, 21:2 (2012), pp. 171-86; Pablo de Greiff and R Duthie, eds., Transitional Justice and Development: Making Connections (New York: SSRC, 2009)

${ }^{5}$ See, inter alia, United Nations (UN) Updated Set of Principles to Combat Impunity (UN Doc. E/CN.4/2005/102/Add.1); UN Basic Guidelines on the Right to Remedy and Reparation for Victims of Gross Violations of Human Rights Law and Serious Violations of International Humanitarian Law (UN GA Resolution
} 
For Latin America, clustering of truth, justice and reparations, particularly, into an apparently consubstantial whole, and the use of 'rights talk' about them, is increasingly apparent in recent public policy discourse, and, sometimes, judicial practice, in and about Colombia, ${ }^{6}$ Argentina, ${ }^{7}$ and Brazil, ${ }^{8}$ for example. The incipient trend towards 'bundling' TJ-related measures into an indivisible set can perhaps be most clearly seen in the activities of the two-tier Inter-American human rights system, uniquely activist on TJ matters at least since the founding of the Court founding in 1979, at the height of dictatorship-era violence. ${ }^{9}$ Both Commission and Court regularly produce recommendations or verdicts making explicit reference to multiple TJ dimensions. ${ }^{10} \mathrm{~A}$ recent Commission report on the right to truth for example, meticulously explores justice, reparation and reform measures as directly pertinent, if not integral, to delivery of full truth. ${ }^{11}$ Time has also shown the dimensions of TJ to be are in practice inextricable, since a single measure often

60/147), and reports by the UN Special Rapporteur on the Promotion of Truth, Justice, Reparations and Guarantees of Non-recurrence to the UN General Assembly (UN Doc. A/69/518, 14 Oct. 2014); and to the UN Human Rights Council (UN Doc. A/HRC/27/56, 27 Aug. 2014 and UN Doc. A/HRC/21/46, 9 Aug. 2012).

${ }^{6}$ Viz. the Victims and Land Restitution Law of 2011, and ongoing peace negotiations which have, unusually, explicitly foregrounded transitional justice concerns and the language of victims' rights, most recently in. interim justice and reparations agreements signed in mid-December 2015.

${ }^{7}$ Argentina pioneered an explicitly rights based approach within particular dimensions (viz. the 'right to truth', Lapacó case, Inter-American Commission, 2000). The interconnection between dimensions has also been used to leverage advances at times of apparent stasis, as when the 1990s 'truth trials' used judicial processes to produce factual revelation even when amnesty still precluded punishment. It remains to be seen how the 2016 change in government may however affect a transitional justice policy process that had become increasingly politically partisan under Cristina Fernández de Kirchner (2007-2015).

${ }^{8}$ The powerful symbolic and reparatory effects of the Brazilian Amnesty Commission's 'Memory Caravan' hearings, acknowledging former political prisoners, have helped fuel wider truth and justice demands, paving the way for a fully-fledged official truth commission which reported in December 2014. Individuals associated with the Amnesty Commission have also promoted an active country-wide university TJ network and supported efforts by a handful of state prosecutors to open criminal cases for torture. See www.rlajt.com; or http://transitionaljusticeinbrazil.com/

${ }^{9}$ Alejandra Huneeus, 'Courts Resisting Courts: Lessons from the Inter-American Court's Struggle to Enforce Human Rights', Cornell International Law Journal, 493 (2011) pp101-155.

10 The Court typically insists on a strong duty to prosecute and punish, requiring 'due expedition' of judicial proceedings together with state acknowledgment (truthtelling) and economic or symbolic reparations. See inter alia Inter-American Court cases La Cantuta v. Peru (2006); Almonacid (2006) and García Lucero (2013) v. Chile; Gomes Lund v Brazil (2010); Gelman v. Uruguay (2013), and El Mozote v. El Salvador (2012). ${ }^{11}$ Inter-American Commission on Human Rights (IACHR), 2014, 'The Right to Truth in the Americas' OEA/Ser.L/V/II.152 Doc.2 
has an impact across more than one dimension. Thus, memorialisation can have preventive and reparatory aspects, civil cases are one route to economic reparation, and criminal proceedings may reveal truth as well as providing justice. ${ }^{12}$

A 2013 London conference discussing rights-based transitional justice experiences in Latin America suggested that in the past, these dimensions were often demanded and delivered in disaggregated ways. ${ }^{13}$ Thus groups might campaign for - and transitional states deliver (or not) - initiatives such as truth commissions to resolve the question '¿Dónde Están?' ('where are they?’), regarding the disappeared. At another moment, an anti-impunity campaign might seek to challenge the status of amnesty. Reparations might be addressed separately, if at all. It is arguably more common today than it was previously to find organisations and campaigns with multiple, rather than single-issue, agendas. ${ }^{14}$ Is this more holistic agenda, where truth, justice, reparations and/or forward-looking reforms can be seen or claimed as a bundle of related entitlements, also visible in official TJ practice or policy? Do authorities, for example, today create multi-purpose TJ agencies, rather than standalone truth, justice or reparations instances? Do new measures, such as the Brazilian truth commission, appear intended to deliver simultaneously across more than one dimension? Are states with relatively long transitional justice histories showing signs of actively seeking to increase connect

\footnotetext{
${ }^{12} \mathrm{~A}$ fact often overlooked in debates over the relative merits of truth or justice. As Wilde remarks, for Chile, "[h]istorical truth was uncovered above all through the pursuit of justice." Alexander Wilde, 'A Season of Memory', in Cath Collins, Katherine Hite and Alfredo Joignant, eds, The Politics of Memory in Chile (Boulder: Lynne Rienner, 2013), p. 39. See also Daniela Accatino and Cath Collins 'Truth, Evidence, Truth: The Deployment of Testimony, Archives and Technical Data in Domestic Human Rights Trials', Journal of Human Rights Practice, forthcoming, 2016.

${ }^{13}$ Conference 'The right to truth, justice and reparations in Latin America', Institute for the Study of the Americas, University of London, 4 June 2013.

${ }^{14}$ At least for Chile, the setting with which this author is most familiar. Expansive group agendas, particularly notable since 1998, now commonly include 'verdad, justicia y reparación integral (truth, justice, and holistic reparations)' or verdad, justicia y memoria ('truth, justice and memory'). Some groups have explicitly chosen to link historic demands to contemporary rights claims in a desire to strengthen both: see for example an access to truth campaign pursued by a network of Chilean memory site groups www.londres38.cl
} 
and overlap between dimensions in existing instances, or to iron out previous interference or negative synergy through policy innovation?

Case study: The interconnectedness of truth with other transitional justice dimensions in presentday Chile

This paper explores these questions through a case study of recent measures in one setting. Chile, a classic example of Latin American authoritarian-to-democratic transition, has a long and rich transitional justice history including at least some measures in each of the four abovementioned dimensions. It has also seen significant planned and unplanned TJ innovations, and shifts and sometimes reversals in each of them, since its 1990 return to electoral democracy. These innovations include an early (1991) official truth commission plus a second such instance, over a decade later. Chile therefore offers a unique opportunity to study an empirically rich, long-running (25 year) transitional justice trajectory that includes two truth commissions and significant recent contestation around new TJ practice..$^{15}$

Recent developments in Chile's management of dictatorship-era legacies are undeniably significant. They include, as well as the second truth commission, interpretive narrowing of blanket amnesty (leading to perpetrator prosecutions); ratification of new international human rights instruments; and the inauguration of a Memory Museum, National Human Rights Institute, and Human Rights Secretariat. Often proudly cited by the Chilean state as evidence of its continued prioritisation of

${ }^{15}$ All Chile's TJ policy innovations and modifications have been surrounded by, indeed driven by, competing right, left, and military tensions as much as by enlightened elite policymaking. See below and Cath Collins 'Human Rights Policy under the Concertación', in Peter Siavelis and Kirsten Sehnbruch (eds.) Democratic Chile: The Politics and Policies of a Historic Coalition, 1990-2010 (Boulder: Lynne Rienner, 2014), pp. 143-72; or Cath Collins, 'Chile a más de dos décadas de justicia de transición', Política, 51:2 (2013), pp. 79-113. 
responses to dictatorship-era abuses, ${ }^{16}$ these initiatives are nonetheless quite consonant with the historically subdued, reactive, and generally low key attitude by Chilean authorities to transitional justice challenges. ${ }^{17}$ Closer examination reveals relatively little evidence of design for longevity, an option for 'joined up' TJ policy, or conscious modelling of interventions on regional or international standards. Policy initiatives continue rather to be stubbornly, perhaps even increasingly, temporary in duration, and insulated or isolated one from another. ${ }^{18}$

\section{Focus and sources}

This paper discusses recent innovation along the truth dimension of Chilean TJ policy; specifically, the second official truth commission ('Valech Commission'), which functioned in $2004 / 5$, with a second iteration in $2011 .{ }^{19}$ The paper discusses both the sufficiency of the Valech endeavour as a truth measure, and its interrelationship, or not, with justice and reparations. After showing that Chile's most recent truth measure attempted to isolate truth advances from justice, while linking them strongly and explicitly to reparations, I go on to discuss the practical and conceptualtheoretical problems illustrated by and associated with each of these characteristics.

\footnotetext{
${ }^{16}$ See for example official submissions to the Inter-American Court in the Almonacid and García Lucero cases (2006 and 2013), Universal Periodic Review submissions to the UN Human Rights Council (2009 and 2014), and authorities' responses to the 2012 report of the UN Working Group on Forced and Involuntary Disappearances' mission to Chile (on file with author).

${ }^{17}$ Anne Pérotin refers to the "extreme discretion" with which the political class proceeded on this issue in the 1990s, and José Zalaquett to a "reactive attitude" in the same period. Anne Pérotin-Dumon, "El pasado vivo de Chile en el año del Informe sobre la Tortura', Nuevo Mundo, Mundos Nuevos 5 (2005); and José Zalaquett, 'No Hay Mañana Sin Ayer: Análisis de la Propuesta del Presidente Ricardo Lagos sobre Derechos Humanos', Estudios Públicos 92 (Spring 2003), pp. 29- 62.

${ }^{18}$ See the National Human Rights Institute, INDH, Informe Anual 2013, available from www.indh.cl and the INDH's associated 2013 memorandum on the human rights subsecretariat draft bill (http://www.indh.cl/wpcontent/uploads/2012/09/Minuta-subsecretaria-DDHH1.pdf-ok1.pdf ).

${ }^{19}$ Henceforth, the term 'Valech II' will be employed when specific reference to the 2011 iteration is needed, though 'Valech' will also be used generically, where appropriate, to refer to both iterations.
} 
Valech has to date been relatively little-studied, especially in English-language scholarship. ${ }^{20}$ Moreover, the policy isolation described above, which it exemplifies, has recently come under sustained pressure from civil society and the judicial branch. (A secrecy law barring access to its archives was partly overturned in 2014 , allowing some judicial access, while in 2015 , survivors sought to expand its remit, improve reparations, and introduce linkages to justice). Both of these facts make Valech a suitable and indeed obligatory object of study for scholars interested in the political and sociolegal dynamics surrounding real-world truth commission operation; the pressures that can arise as the boundaries between truth, justice and reparations ramifications of a single instance, or the implications of piecemeal versus holistic approaches to TJ. Aspects of particular theoretical and comparative interest include the sharp contrast between an evident official desire to finally close a chapter in the country's TJ history, by addressing survivors' needs more fully than before, and the actual effect of Valech in fuelling renewed criticism and activism from that same constituency.

The commission dealt with political imprisonment and torture, acknowledging a total of almost 39,000 individual survivors. ${ }^{21}$ 'Sober and austere' reparations had already been promised as a likely corollary. The prologue to the report's initial conclusions also mentioned forward-looking rights protections - which could be understood as guarantees of non-repetition - and a "juridical and economic" dimension to individual reparations. It was, however, made clear that the "juridical dimension' meant "restoring the dignity of [survivors],"22 rather than perpetrator prosecutions, of

\footnotetext{
${ }^{20}$ Exceptions include Elizabeth Lira and Brian Loveman 'Torture as Public Policy, 1810-2011', in Collins, Hite and Joignant (eds.), op. cit., pp.91-132 (volume also published in Spanish as La Politica de la Memoria en Chile: desde Pinochet a Bachelet, Santiago: UDP, 2014) and, in Spanish: Pérotin-Dumon, op.cit., and Zalaquett, op.cit.

${ }^{21}$ For perspectives on the commission's origins see below, Wilde (op. cit.), and Elizabeth Lira and Brian Loveman, 2014, op. cit.. Lira was a member of both iterations of the commission.

22 Taking the form of, for example, wiping criminal records for those whose only offence had been political opposition to the regime.
} 
which no mention was made. There was, however, reference to the "privacy" of commission proceedings. ${ }^{23}$ In the event, existing 'Rettig reparations' - provisions for victims' relatives - were updated, then extended in a modified form to survivors named in the Valech lists. ${ }^{24}$ Meanwhile, immediate justice implications were not only de-emphasised but were rendered impossible, by means of a 50-year secrecy law forbidding public and judicial access to any Valech deliberations, testimony, or background documents. ${ }^{25}$ This tension between truth and justice was particularly acute, and became the faultline around which future controversy coalesced.

For sources, this paper draws heavily on original material produced by the Human Rights Observatory ${ }^{26}$ of Chile's Universidad Diego Portales (UDP), from close on-the-ground observation since 2008 of key events in Chilean TJ. This material includes records of seminars convened by the Observatory, news summaries published as regular electronic bulletins, and seven iterations of an annual national human rights report published by the UDP. In the interests of space and readability, these documents are not always individually referenced in full in each section of the paper. All are freely accessible from the Observatorio Justicia Transicional section of the website www.derechoshumanos.udp.cl. The paper also draws on numerous interviews with actors in, and users of, the Valech Commission and subsequent measures. Around 35 interviews were carried out between 2004 and 2015, clustered in 2004-05, 2012-13, and 2015. Observatory researcher Jennifer

\footnotetext{
${ }^{23}$ Message by then-president Ricardo Lagos (2000-2006), Valech report prologue, pp 2 and 3, author's translation.

${ }^{24}$ Valech's initial 2004 round produced a substantial printed report accompanied by survivor lists. In 2005, appendices of newly recognised cases were added. The 2011 iteration produced only a victim list and accompanying statistics. See Observatorio DDHH: 'Taller Comisión Valech II - Aspectos Metodológicos' available via www.derechoshumanos.udp.cl

${ }^{25}$ Supreme Decree No 1,040, of 26 September 2003, Art 5, establishes 'reserve for all legal effects' (author's translation), as does Law 20.405, of 10 Dec. 2009, Transitory Article 3, para 6, subsection 1.

${ }^{26}$ Known since 2014 as the Observatorio de Justicia Transicional.
} 
Herbst carried out the 2012 interviews. The author is indebted to her and to other members of the Observatory team. ${ }^{27}$ All conclusions drawn remain the sole responsibility of this author.

\section{Structure and conceptual framework}

This paper's starting premise is the empirical contention, made above, that an emerging regional and international norm set seeks to construct a moral and/or legal duty on states to essay the comprehensive delivery of truth, justice and reparations after past political violence. ${ }^{28}$ Such a framework is unambiguously normative, derived from aspirations and standards in soft law, guidelines, and jurisprudence rather than codified law or positive treaty obligations. ${ }^{29}$ Accordingly, and correctly, disputed and critiqued, the empirical existence and in-region influence of this framework is nonetheless undeniable. It is also useful for allowing something substantive, and potentially comparative, to be said about a particular country's present transitional justice practice.

This paper will accordingly go on to discuss the strengths, weaknesses, achievements and limitations of the Valech truth initiatives, and subsequent developments, with reference to this framework. The paper however allows for the possibility that the framework itself, rather than Chile's specific practice, may thereby be found wanting. In other words, it remains agnostic regarding the validity

\footnotetext{
27 Since 2008, Juan Pablo Delgado, Mayra Feddersen, Karinna Fernández, María Florencia González, Boris Hau, Rodrigo Hernández, Jennifer Herbst, Alice Pfeiffer, Antonio Poveda, Tabata Santelices, Maria Ignacia Terra, Camila Varela, and Paulina Zamorano. The project received initial funding support from the Ford Foundation and the Heinrich Boell Foundation.

${ }^{28}$ This development is both clearly visible and critically analysed in an abundant academic and practitioner literature, generalist and Americas-focused. See, inter alia, Susanne Buckley-Zistel et. al, eds., Transitional Justice Theories (Abingdon, Routledge, 2014); Par Engstrom, 'The Inter-American Human Rights System and Transitional Justice in Latin America', remarks to the conference 'Putting the State on Trial', Ulster University, Belfast, 17 October 2013; Félix Reátegui (ed.) Transitional Justice: Handbook for Latin America (Brasilia, NY: Brazilian Ministry of Justice/ ICTJ, 2011); SLADI, 'Justicia Transicional en América Latina: Primer Informe del grupo de trabajo', 2011; Kathyrn Sikkink, The Justice Cascade (NY: Norton, 2011); Kai Ambos, Ezequiel Malarino and Gisela Elsner (eds.), Justicia de Transición (Montevideo: Konrad Adenauer Stiftung, 2009), Naomi Roht-Arriaza and Javier Mariezcurrena Transitional Justice in the Twenty-First Century (Cambridge: Cambridge University Press, 2006).

${ }^{29}$ For now-extensive jurisprudence from domestic courts see Due Process of Law Foundation (DPLF); Digest of Latin American Jurisprudence on International Crimes Vols 1 and 2 (Washington DC: DPLF 2010, 2013), and Digest of Latin American Jurisprudence on the Rights of Victims (Washington DC: DPLF, 2015).
} 
or superiority of holistic TJ rights framings and expectations, suggesting that important questions about synergy, compatibility and viability remain unaddressed. In so doing, it follows Leebaw and others in challenging the maximalist aspirations of certain evangelical approaches to transitional justice advocacy. ${ }^{30}$

Emerging norm sets surrounding truth, justice and reparations

Maximal, and maximally holistic, approaches to TJ tend to be associated with increasingly ambitious and developed sufficiency standards for each dimension. These include for example the proposition that truth should be public, reliable, complete, and widely-known; while also being a step towards timely, proportional, and proactive justice. ${ }^{31}$ Under such a schema, states wishing to fully meet international obligations to prosecute and punish serious violations can probably no longer merely tolerate claimbringing by victims and/or third parties. ${ }^{32}$ Nor is it acceptable to impede prosecution or abrogate the possibility of punishment through blanket domestic amnesty and/or statutes of limitation, at least for war crimes and crimes against humanity. States are increasingly expected to demonstrate an active prosecution policy for those crimes that clearly require it. ${ }^{33}$ Reparations are

\footnotetext{
${ }^{30}$ Bronwyn Leebaw, 'The Irreconcilable Goals of Transitional Justice', Human Rights Quarterly 30 (2008) pp. 95-118. See also Padraig McAuliffe, 'Transitional Justice's Expanding Empire', Journal of Conflictology 2: 2, 2011, pp. 32-44.

${ }^{31}$ In addition to the UN Rapporteur documents cited at supra n.5, see Cristián Correa, 'Reparation Programs for Mass Violations of Human Rights', in Reátegui, op. cit., pp. 409 ff. Correa argues strongly for coherence and mutual reinforcement between truth, justice and reparations measures to become a fundamental TJ design principle.

${ }^{32}$ Many Iberoamerican legal systems allow victims, NGOs or civil society associations to act as direct complainants in the criminal as well as civil justice system. However, full state compliance is arguably now being interpreted as requiring 'de officio', state-initiated, prosecution. See, inter alia, Inter-American Court of Human Rights, García Lucero v Chile, Sentence of 28 Aug. 2013, and UN Special Rapporteur Report to the UN Human Rights Council on Prosecutorial Prioritization Strategies in the Aftermath of Gross Human Rights Violations and Serious Violations of International Humanitarian Law (UN Doc. A/HRC/27/56, 27 Aug. 2014).

${ }_{33}$ Outer limits to the acceptable use of amnesty and similar devices are increasingly enforced in the InterAmerican human rights system. See, particularly, Par Engstrom and Andrew Hurrell, 'Why the Human Rights Regime in the Americas Matters', in Mónica Serrano and Vesselin Popovski (eds.), Human Rights Regimes in the Americas (Tokyo: United Nations University, 2010). The region's existing domestic amnesties have almost without exception been challenged or interpretively narrowed in recent years, while the frequency of their adoption as initial transitional devices also declines over time. See Cath Collins, 'The End of
} 
also increasingly conceptualised as necessarily comprehensive - dealing, for instance, with consequences for mental as well as physical health; taking account of referred, including intergenerational, harm, and allowing for genuine victim participation and respect for victims' dignity. ${ }^{34}$ How does Chilean TJ practice, particularly around truth initiatives, measure up alongside these admittedly exacting standards? Some necessary factual background on Chile's truth commission sequencing follows, before Valech is explored in more depth.

\section{Truth Commissions in Chile: from Victims to Survivors}

Chile's first truth commission, the National Commission on Truth and Reconciliation (CNVR or 'Rettig Commission', 1990-91) acknowledged deaths and disappearances during the 1973-1990 military dictatorship, ${ }^{35}$ but did not individualise cases of survived torture. A successor body set up to complete case classification reported in 1996, and an accumulated total of 3,195 victims was thereby acknowledged. These results will be referred to under the generic title 'Rettig'. Truth was connected both to reparations and to justice in this phase. Reparations, including a modest monthly pension, were extended to the immediate family of all those named in the accumulated lists. ${ }^{36}$ Background information on cases submitted to Rettig, whether finally acknowledged or not, was

Impunity?', in Nicola Palmer, Phil Clark, and Danielle Granville (eds.), Critical Perspectives in Transitional Justice (Antwerp: Intersentia, 2012) pp. 399-423; Louise Mallinder 'The End of Impunity?' forthcoming, 2016; or Cath Collins, Jemima García Godos and Elin Skaar (eds.), Transitional Justice in Latin America: The Uneven Road from Impunity towards Accountability (Routledge: forthcoming, 2016).

${ }^{34}$ See Pablo de Greiff (ed.), The Handbook of Reparations (Oxford: Oxford University Press, 2006). Brazil's Amnesty Commission, spearheading a reparations-led TJ process, has been particularly inventive. See Marcelo Torelly and Paulo Abrão, 'The Reparations Program as the Lynchpin of Transitional Justice in Brazil' in Reátegui, op. cit., pp 443-85; and 'Resistance to Change', in Francesca Lessa and Leigh Payne (eds.) Amnesty in the Age of Human Rights Accountability (Cambridge: Cambridge University Press, 2012), pp. 15281.

35 Including non-attributed and non-state violence.

${ }^{36}$ Law 19.123, 8 Feb 1992. Other measures instituted around the same time, including access to the public health system, were extended to various categories of victim and survivor including Rettig families. 
sent to the courts. This brought little immediate justice change, since judicial practice in 1991 and 1996 was resolutely pro-impunity. It nonetheless represents a significant difference between this commission and the subsequent one: Rettig, unlike Valech, left open a connecting door between truthtelling and justice.

Chile's second official truth commission, officially entitled the National Commission on Political Imprisonment and Torture, was announced in mid-2003, as part of a broader 'human rights policy package' entitled 'No Hay Mañana sin Ayer'. The timing is suggestive: the decision came in the aftermath of a groundswell of justice demands (see below). The commission, chaired by senior cleric Sergio Valech, became the centrepiece of the new policy announcement. Operating between 2004 and 2005, Valech received testimony and documentation in Chile and abroad from or on behalf of people who had survived politically-motivated detention or torture by state agents between 1973 and 1990. People eventually came forward in unexpectedly large numbers: the original deadline had to be extended, and additional statement-takers hired, as the sobering range and depth of atrocities hitherto largely ignored came into focus. Valech's final published report served as a grim catalogue of the depths to which the regime had sunk in efforts to dehumanise and break its perceived enemies. Additional classifications in an appendix gave a 2005 total of almost 29,500 recognised survivors.

The public impact of Valech on its initial 2004 release was substantial, perhaps even greater than that of Rettig in its day. At a longer distance from events, and against the backdrop of the gradual political and judicial discrediting of Pinochet and some of his more notorious henchmen, details emerged of crimes including the setting of dogs on naked female prisoners, the torture of children to make their parents talk, or the 'collateral damage' of miscarriages induced through sustained beating and sexual assault of incapacitated, blindfolded prisoners. These accounts were hardly 
susceptible to the 'exigencies of war' justifications that some had found at least plausible with regard to the deaths of militant young men in the immediate aftermath of the coup.

'Valech II', in 2011, came about largely as a result of battles by human rights organisations on behalf of survivors who had not previously testified, or whose cases had not been recognised. A smaller group of relatives of hitherto unacknowledged victims of death and disappearance wanted their relatives added to the Rettig register. In the event, after a new, shorter, period of testimony gathering and research in 2011, almost 10,000 additional survivors, plus thirty new death and disappearance cases, were acknowledged by Valech II. This iteration did not produce a report, but only a statistical account and list of names. Public and media attention was accordingly muted, not least because the new iteration was concluded under a right-wing administration clearly embarrassed by the whole exercise, which had begun under the previous dispensation. Meanwhile survivors, a constituency Valech II had been intended to placate, were in fact incensed by the yet again temporary nature of the instance, plus the low rates of endorsement of applications made (only around a third of cases proposed were acknowledged by Valech II, down from around 60\% for Valech I).

\section{Origins of 'Valech': Why a second truth commission, and why in 2004?}

Like much of Chile's patchwork of official transitional justice measures, Valech's origins lay as much in extra-official chivvying and lobbying as in executive decisiveness, moral leadership, or strong political will. Pressure to act came from the human rights sector, but also some conservative sectors, convinced by the course of events that further action on the 'human rights question' could no longer be avoided. The 1998 justice 'irruption' - domestic cases against Pinochet plus his October arrest in the UK - loomed large for both sectors. A roundtable, carried out in the year 2000 ostensibly to 
'resolve' the issue of the disappeared, had clearly proved insufficient. Pérotin (op.cit., pp. 3-6) attributes Valech "partly" to pressure from human rights organisations and survivors, listing additional precipitating and contextual factors. These included the fact that the whole question of torture, having become central to extradition wrangling in the UK Pinochet case, remained nationally visible: in 2001, Pérotin's colleague Emilio Meneses, a lecturer at the conservative Catholic University of Santiago, was accused by a fellow academic of direct involvement in 1970s torture. The issue became a brief cause célèbre. ${ }^{37}$ By 2002 intense judicial activity begun in 1998 was about to culminate, with several major cases about to reach a verdict. Anticipation of the $30^{\text {th }}$ anniversary of the coup, due in September 2003, stimulated unprecedented amounts of television coverage and artistic production. Several emblematic former torture centres were declared national monuments. In all says Pérotin, Chile embarked on a "literal and figurative exhumation of its past", (op. cit., p 6, my translation), making some kind of executive gesture or announcement almost inevitable.

The psychiatrist Dr. Paz Rojas, director of the historical human rights organisation CODEPU and a longstanding campaigner on behalf of torture survivors, adds a more personal note. She suggests that individuals respected by then-president Ricardo Lagos, and close to his and his wife's inner circle, consistently and insistently put to him, around this time, the need to give the newly-visible survivors' movement specific recognition, taking torture and its lingering social effects seriously. ${ }^{38}$ Respected jurist, and former Amnesty International president, José Zalaquett frequently advised Lagos on human rights questions. Speaking at an August 2003 seminar (proceedings later published as Zalaquett, 2003, op. cit.), Zalaquett addressed the recently-released presidential proposals which

\footnotetext{
${ }^{37}$ Patricia Verdugo (ed.), De la Tortura No se Habla (Santiago: Catalonia, 2004). Meneses was suspended then reinstated, amidst lawsuits for defamation during which the accuser, himself a torture survivor, was vindicated.

${ }^{38}$ Author interview with Dr. Paz Rojas, Santiago, January 2013.
} 
contained the germ of the future Valech Commission. Referring to an "enormous" increase in rates and effectiveness of judicial investigation Zalaquett suggested that this and other recent events had precipitated recognition in military and right wing political circles that deeper remedies were needed (Zalaquett, op.cit. p. 45; p. 64).

Zalaquett also addresses an issue often overlooked in subsequent discussions of Valech: Lagos's original, mid-2003, draft proposed measures to extend concessions and incentives to perpetrators. The proposals, which did not prosper, would have offered 'limited immunity' for those who gave useful information about the disappeared, and early release for those already serving prison time who were willing to co-operate. The pill was to be sweetened by extending similar leniency to members of rump armed leftist groups, imprisoned for violent crimes committed after transition. Zalaquett acknowledged the legitimate apprehensions of some, including relatives' groups, about tying such proposals to suggested truth and reparations advances. These apprehensions were certainly shared by survivors, who would not countenance what they saw as further impunity. Their opposition appeared to win out, and associations of former political prisoners began to proliferate, organised by region, political militancy, or affinity group. They agreed about little except, increasingly, about the need for 'more' - more truth, more justice, and reparations to put them at least on an equal footing with the victims' relatives who had for so long been Chile's main reference group for victimhood.

\section{$\underline{\text { Truth, Justice and Reparations in the Leadup to Valech }}$}

In the leadup to the first Valech iteration, campaigners had two principal sets of concerns. First, what would be the relationship between this new initiative and justice? Rettig had handed results to the courts, but at a time when amnesty protected perpetrators and the courts were demonstrably not interested in pursuing cases. How would the new commission negotiate or acknowledge a new 
justice climate much more favourable to accountability? Second, how would it affect existing reparations? This concern was driven by the fear of regression. Some torture survivors already had health entitlements and modest pensions, through schemes recognising other aspects of victimisation. ${ }^{39}$ Would survivors whose cases were not now acknowledged by Valech lose access to these services?

Answers emerged gradually as the terms of reference of the new initiative became known. Regarding the first, the 50 -year secrecy law ${ }^{40}$ actively forbade the redirection of material from the new truth commission into the judicial domain. It was, however, acknowledged that documents supplied by survivors to the Commission remained inalienably their own, to do with as they saw fit. The stated purpose of the secrecy law was, after all, not to dissuade justice activity but to protect survivor privacy to maximise the numbers who felt able to come forward. Nonetheless, the exact meaning of the 'personal property' exception was not spelled out, giving rise to contrasting later interpretations. Decisions about function also affected form: the standardised record sheet completed on behalf of each person (or which individuals could self-complete) did not designate space to record the name of any mentioned perpetrator. The Commission archive is accordingly likely to have less specific evidentiary value than is sometimes believed, although files contain additional background research by staff.

\footnotetext{
${ }^{39}$ See details and tables in Collins (2014) op. cit.

${ }^{40}$ Initially to be set at thirty years, the term was extended to 50 years in the final text of the law. Thenpresident Ricardo Lagos generally offers a personalist, victim-focused explanation for this hike, stating that it proceeded from meeting a survivor keen to impress upon him her fervent desire to be sure that her children and grandchildren could not see her testimony within her lifetime. Advisers close to his office at the time also cite the precedent set by Brazilian president Fernando Henrique Cardoso, who Lagos admired: in 2002, Cardoso bowed to Armed Forces pressure and signed off on an upward extension, to 50 years, of secrecy periods on official documents.
} 
Regarding the second concern, about the interaction between different kinds of entitlement, the law that established 'Valech reparations' ${ }^{\prime 11}$ did not attempt - as had the previous, 'Rettig', version - to make Valech payments, Rettig pensions, and other reparations that might be obtained in future (eg by a civil lawsuit) mutually exclusive. It did, however, make the new pension incompatible with pensions previously awarded under the separate 'exonerados politicos' programme. ${ }^{42}$ Survivors recognised by both instances would have to opt between entitlements. Those recognised by Valech who had previously been admitted, on other grounds, to the 'PRAIS' health programme - which, importantly, offered specialist mental health support - would continue to be entitled, and people recognised by Valech but not previously in PRAIS could now join. A question mark initially remained over those previously admitted to PRAIS on its own, in-house, criteria whose cases were not accepted by Valech. Fears that such individuals might be denied treatment, or even fall under suspicion of fraud, have to date proved mostly groundless, but did not seem at all fantastical at the time ${ }^{43}$ Nor were they allayed by any official announcement: if anything they were fuelled when, during the runup to Valech II, the Health Ministry ordered PRAIS to produce the first ever central register of accredited users. ${ }^{44}$

\section{Definitions}

\footnotetext{
${ }^{41}$ Law 19.992, 24 Dec. 2004.

${ }^{42}$ For people sacked from their jobs for political reasons during the dictatorship.

${ }^{43}$ Legal proceedings for fraud were in fact instigated against a few dozen unsuccessful Valech applicants, and some prior applicants to the exonerados programme. See Observatorio DDHH, 'Verdad, Justicia y Memorialización por Crímenes del Pasado', Informe Anual sobre DDHH (UDP, Santiago, 2012) and 'Verdad, Justicia y Memoria a 40 años del golpe de Estado', Informe Anual sobre DDHH (UDP, Santiago, 2013). The 2013 report is also available in translation.

${ }^{44}$ At that time the Ministry, like all official bodies including Valech II itself, was operating under a right wing administration (sworn in in 2010). Many survivors were instinctively suspicious of intervention by a right wing government in this issue area. PRAIS programmes were however allowed to continue operating according to their own, ad hoc, earlier criteria of admission, without further explicit discussion.
} 
As we have seen, Rettig had proceeded on the assumption that torture could not be satisfactorily individualised. Preserving this contested assumption, while at the same time designing a mechanism that would satisfy survivors' demands, was a difficult circle to square. Zalaquett, op. cit., gives a clue to the solution eventually adopted by Valech: cases could be accredited on the basis of political imprisonment alone, leaving torture to be secondarily or tacitly acknowledged based solely on testimony. Thus the definitional problem surrounding torture was simply displaced onto definitions of political imprisonment. In the event, Valech adopted the following definitions: political imprisonment was understood as arbitrary detention, carried out for political motives, by state agents or persons at their service, between 11 September 1973 (the date of the military coup) and 10 March 1990 (the date of formal transition) 'Arbitrary' detention was understood as detention not based on a pre-existing legal norm; detention based on laws which, while technically valid, were not in accordance with recognised international human rights principles; detention which was prolonged beyond what might be considered reasonable; or detention carried out by, or followed by, violation of the rights of the detainee. ${ }^{45}$ Torture was defined as " any action by which a person has been intentionally subjected to serious physical or mental pain or suffering, with the aim of obtaining from that person, or a third party, information or a confession; punishing him or her for something that she or he has done or is accused of having done; intimidating or threatening that person or others, breaking his or her character or damaging his or her physical or mental integrity, or giving expression to any kind of discriminatory treatment. This presupposes that such pain or suffering has been inflicted by a state agent or person at the service of the state, or acting at the instigation, with the consent, or with the forbearance of such a person". ${ }^{46}$ The report stated that

\footnotetext{
${ }^{45}$ Informe, Comisión Nacional sobre Prisión Política y Tortura (2004), pp. 21-22, author's translation.

${ }^{46}$ Informe, op.cit., p. 19, author's translation.
} 
this working definition had been derived from the prevailing International, and American, Conventions against Torture.

The principal significant exclusions were of people detained en masse after street protests, and people whose detention lasted less than 48 hours or was carried out in 'irregular' settings, including outside Chilean territory. The report however suggests that some such cases were included if the Commission was persuaded by evidence of their having been tortured, introducing a grey area as to the actual basis on which classifications were made. ${ }^{47}$ In the event, $94 \%$ of those acknowledged in 2005 as survivors were declared to have been tortured as well as suffering political imprisonment (Informe, op. cit., p. 8).

What Valech did and did not do: the careful construction of the 'dejudicialised' survivor

The emergence of survivors as a collective, rights-bearing subject challenged the existing de facto 'hierarchy of victims', which had emerged in Chile over the years as it does in many post-transitional and post-conflict settings. Certain groups come to inhabit, whether deliberately or not, the centre of a set of virtual 'concentric circles' at whose heart official concern and public attention are more prevalent and group demands are more likely to be attended to. In Chile, the disappeared and their relatives occupied the centre ground. Relatives of victims of political execution came next. Survivors had generally occupied a more peripheral place. They were considered and consulted, if at all, primarily as potential sources of intelligence about the fate of others: the dead, the disappeared. Prior to Valech, their place in the public policy matrix was also largely subsidiary. They might be 'patients', if they availed themselves of health services through PRAIS. They might, if they had been

\footnotetext{
${ }^{47}$ Informe, op. cit., p. 9.
} 
blacklisted or forcibly exiled, have access to pension credits or similar. ${ }^{48}$ But the sole, stark fact of having been locked up, beaten, and abused in the most unspeakable ways by agents of the state had not in itself been deemed worthy of individual acknowledgement or redress.

There are many reasons for this, not all as simple as official dereliction of duty. Amongst genuinely political active regime opponents, to have survived at all was somehow suspect -it was often assumed, rightly or wrongly, that activists who were released had broken or been turned. Others scarcely considered themselves 'true' victims at all. These included non-politically active individuals; those never detained but 'only' beaten and abused during house to house searches; and women, children or elderly relatives tortured or held hostage in their own homes to trap unsuspecting family members. A full discussion of the politics of victimhood in Chile lies outside the scope of this paper, but the messiness of these overlapping categories of victimhood seems to have escaped those who designed the 2003 policy. Alternatively, it was perhaps felt necessary to subsume the two problems into one, thereby preserving the earlier official assertion that torture could not be individually accredited. A definitional line did, after all, have to be drawn somewhere, and borderline cases would inevitably be generated. Either way, the eventual outcome was a commission that dealt with torture only secondarily to, and through the lens of, political imprisonment.

Those who had pressed for specific attention to the pernicious and lasting social effects of torture protested that the yoking together of the two issues would dilute the specific attention paid to torture. In this they were undoubtedly proved correct. The assertion that torture simply cannot be substantiated with the required degree of certainty at the level of the individual, while roundly disputed, has nonetheless hampered attempts to obtain justice or compensation through the

\footnotetext{
${ }^{48}$ Under the programmes of reparations for exonerados, and for retornados (returnees), respectively.
} 
courts. ${ }^{49}$ Absent access to testimony and other documentation, the fact that Valech accreditation per se only, strictly, speaks to political imprisonment has weakened its utility in court proceedings.

Although reparations had been promised, it was by no means clear at the time that inclusion in Valech would subsequently become the only turnstile for access to the category of recognised survivor. Nor was it anticipated, at least not publicly, that entitlements previously extended to survivors might be withdrawn in future if they refused or neglected to take part. People therefore chose to testify, or not, based on factors other than their views about or need for reparations. What was, however, known was that the 50-year embargo would prevent anyone, including judges, having access to supporting testimony or other source material. ${ }^{50}$

This single fact about Valech is the gulf that qualitatively divides Valech from Rettig. It also constituted both a disincentive and an incentive to giving testimony. More militant ex-prisoner groups felt they were being silenced or bought off. They boycotted the instance, launching their own parallel efforts to publicly denounce torturers. In other cases, of course, the safety net of confidentiality was the only thing that persuaded some people to talk about what they had lived through. One of the many practical and ethical dilemmas raised by subsequent campaigns to change the secrecy law is precisely the difficulty of differentiating after the fact between those who were, and were not, prepared for their testimony to be handed to a judge or made public. ${ }^{51}$ Other

\footnotetext{
${ }^{49}$ After the year 2000, survivors bringing legal claims began to be routinely referred for forensic medical examination by judges at a loss as to how to investigate allegations of historic torture. The search for physical manifestations, or at the very least clear-cut signs of post-traumatic stress disorder (PTSD), became a spurious method for differentiating between group claimants. The absence of a definitive diagnosis of PTSD was erroneously treated by some judges as a direct refutation of the veracity of survivors' accounts. Interview with Dr. Paz Rojas, op. cit., and remarks by claimants and forensic service personnel at a closed seminar convened by the Observatory in 2013.

50 The 2011 iteration, moreover, was not authorised to produce a 'report' but solely a statistical account and list of names.

${ }^{51}$ A point cogently made by Claudio Herrera, who served as the Commission's executive secretary, commenting in a personal capacity. See Observatorio DDHH, 'Taller Comisión Valech II', op. cit.
} 
commissions have resolved the access to testimony dilemma in different ways. Peru's truth commission, for instance, allows limited researcher access to files. Valech was, however, particularly extreme in the blanket nature and length of its intended access embargo. As a truth measure, Valech was thereby regressive with respect to Rettig in at least two significant ways: the complete, publicly accessible nature of the truth produced was lesser in Valech, and connections with one of the other major dimensions of transitional justice - justice itself - were markedly absent in design (and have been only very partially diluted in practice). This attempted severing of justice connections took place, moreover, at a time when the possibility of real judicial action was significantly higher than it had been in 1991. There are many possible interpretations of this growing separation between official truth and official justice. Some senior judicial figures advance a partly pragmatic explanation. There were, they say, genuine fears in their own ranks that the speciallydesignated magistrate system, already working at capacity over death and disappearance cases, simply could not cope with an influx of thousands of new investigations. A more political explanation, which tends to find favour in civil society human rights organisations, is that post-1998 justice reactivation led to executive efforts to pre-empt new justice claims or divert them into truthand-reparations instances. In this interpretation, successive executives, whether of the centre-left (1990-2010 and 2014-present) or centre-right (2010-2014) have attempted to soft-pedal the criminal justice aspect of transitional justice due to tensions, or the fear of tensions, with military, former military, and other conservative circles. ${ }^{52}$

\section{Challenges to Valech secrecy}

\footnotetext{
52 Behind the scenes anti-accountability pressures from the political right and present-day Armed Forces are routinely denied, but just as routinely evident, in day to day monitoring of TJ related events. See Observatorio de Justicia Transicional electronic news bulletins 1-32, since 2009. Numerous author interviews with judicial and police sources over the same period, on file with the author, support the point.
} 
Over the course of 2012 and 2013, the judicial branch became both object and origin of challenges to the secrecy regime surrounding Valech. First, in 2012, individuals whose cases had not been acknowledged in the second iteration requested court orders to enable them to challenge the specific grounds on which they had been turned down. The arguments included those of equality: the 2004/5 instance, Valech I, had a personal notification and appeals system which the 2011 iteration lacked. Although most of these initial applications failed, the INDH decided in late 2012 to seek a definitive ruling from the Comptroller General's Office, Contraloría, as to the terms of its inherited role as keeper of the files. The result broadly upheld a strong interpretation of the duty of secrecy. ${ }^{53}$ Chile's second Universal Periodic Review before the United Nations (UN) Human Rights Council, on 28 January 2014, produced a recommendation that Valech confidentiality be repealed. ${ }^{54}$ The issue was also referred to in the 2013 campaign manifesto of Michelle Bachelet - who began a second (non-consecutive) term as the country's president in March 2014 - albeit in the vaguest possible terms. ${ }^{55}$ On 10 June 2014, the Contraloria issued a new ruling, in response to a fresh request by the INDH. ${ }^{56}$ Although the ruling itself was extremely non-committal, the INDH chose to interpret it as authorisation to hand information to the courts, on judges' specific request, for cases seen by Valech II - the 2011 iteration - only. This remains the situation at December 2015.

\footnotetext{
53 Dictamen no. 60303, Contraloría General de la República, 1 Oct. 2012.

${ }^{54}$ Report to the UN Human Rights Council of the UN Working Group on the Universal Periodic Review - Chile, (UN Doc. A/HRC/26/5, 2 April 2014), para. 121.116.

${ }^{55}$ Criticism in 2013 of the lack of reference to human rights policy in any major presidential candidate's platform prompted the Bachelet campaign to release a 'civil society consult' document which mentioned 'looking into' the 50 year confidentiality of 'judicial records'. The formulation contained no firm promise of action nor even any dependable reference to Valech, since its documents are certainly no classifiable as 'judicial records'. See Observatorio DDHH 'Truth, Justice and Memory', 2013, op. cit. 56 INDH Ord. 506, 19 Nov. 2013, and, in reply, Contraloría General de la República, Dictamen 41.230, 10 June 2014.
} 
The discrepancy between Valech I and Valech II, indefensible on any common sense grounds, arises due to legal technicalities. ${ }^{57}$ The result is an unsatisfactory and probably unstable equilibrium, in which all involved privately acknowledge as impossible to defend from first principles. The matter moreover illustrates genuine tensions between the right to truth, access to information, and the right to privacy. Information, in the form of raw data, is not a synonym for verified truth, particularly if that data was produced by repressive agencies. Paraguay's Terror Archive, and the former Stasi archive, have faced similar dilemmas regarding records purporting to name informants: in the words of Timothy Garton Ash, "[c]arelessly used, the records of a state that worked by organized lying [...] can ruin lives". ${ }^{58}$ The same issue affects private files, amassed by a secretive, far-right organisation, which were recently released by judicial fiat in Chile. Valech files likewise contain some official, unverified, documentation from or about dictatorship-era security agencies. Most concern, however, revolves around personal survivor narratives offered under confidentiality rules that are now being challenged. Where the right to truth is considered to be collective, rather than inhering in any individual victim, as the Inter-American Court has sometimes suggested, the question of ownership of such narratives becomes thorny. Solutions such as anonymisation of testimony might open the repository to research scrutiny but would not resolve the justice question, while a personby-person retrospective authorisation of release would founder, if nothing else, in respect of survivors who are now deceased.

\section{‘Post-Valech' Developments}

\footnotetext{
57 The statute for Valech I was passed by a qualified majority, whereas Valech II was constituted by a decree law. This distinction was sufficient to allow Contraloría and the INDH to determine that access to information laws allowed an exception to privacy in regard to the latter but not the former. 58 Timothy Garton Ash, cited in Paige Arthur, 'How Transitions Shaped Human Rights', Human Rights Quarterly, 31 (2009) p. 332.
} 
Privacy and information tussles are not the only ongoing reverberations of the 'Valech story'. Like Rettig before it, the instance has proved to be located nearer to the beginning than to the end of a narrative which involves demand inflation, bargaining, and mutual accusations of bad faith. The mere presence of controversy or critique is not sufficient in itself to suggest that the instance was flawed: we are dealing, after all, with a large and diverse group of people subjected to fundamentally irreversible harms, making it difficult if not impossible to imagine a perfectly adequate, and perfectly crafted, state response. Nonetheless, aspects of later difficulties, and the handling of them, could arguably have been foreseen and more adeptly handled. Thus, throughout 2013 and 2014, a range of associations of former political prisoners made representations to the authorities. Their demands were basically twofold: the re-opening of victim and survivor lists on a permanent basis, to allow any case with new information to be (re)considered at any time; and the improvement of the economic reparations associated with Valech recognition. ${ }^{59}$ No response was forthcoming, and in April 2015 groups resorted to the dictatorship-era tactic of a hunger strike. In some senses, the fate of this apparently dramatic gesture confirmed the former prisoners' sense of marginalisation: relatively little press or official attention was paid as over 100 former detainees and torture victims, some in their 70s, starved themselves in a five week protest. In May 2015, however, a bilateral commission ended the protest by effectively postponing the matter. The government offered a oneoff financial 'bonus' plus the promise that a new Human Rights Subsecretariat, to be created at some as yet undefined future point, would revisit the whole issue of survivors' justice and reparations entitlements. ${ }^{60}$

\footnotetext{
${ }^{59}$ The pensions accruing to one and to the other situation were and are widely different, consisting of approximately USD 666 per month for Rettig families, and USD 217 for individuals named by Valech. The discrepancy is partly explained by the fact that the larger, Rettig, amount was designed to compensate an entire family for the loss of a breadwinner, while the Valech pension is personal.

${ }^{60}$ The bonus, of around USD 1,500, was effected in late October 2015. The Subsecretariat was created on paper in mid-December, meaning it will not become operational until well into 2016.
} 
These offers were so far from the immediate, permanent, measures originally demanded that it is difficult to imagine them leading to any permanent solution. For analytical purposes, however, it is of more interest to note that the decision to defer all unresolved matters to a new, generic human rights instance bypassed an obvious existing alternative, thereby constituting a deliberate option against a dedicated TJ agency of the kind discussed earlier in this paper. Thus the existing alternative consisted of the state Human Rights Programme, a somewhat misleadingly named office which has de facto become an embryonic transitional justice agency regarding the dead and disappeared. Having provided social assistance, legal advice, and memorialisation support to relatives since 1996, the Programme began to act independently in criminal cases after 2009. Increasingly loved by relatives and disapproved of by more cautious official elements, the Programme's involvement was made a precondition for negotiation by the 2015 hunger strikers. Its enthusiastic and highly capable young director threw himself into the role, meeting assiduously with survivors' groups and government departments. A detailed, costed proposal emerged which would have turned the Programme into a full TJ agency, mandated to deal with survivors as well as victims, and explicitly empowered to administer truth commission lists and reparations, alongside its existing justice and memorialisation work regarding deaths and disappearances. ${ }^{61}$ The proposal never received an official reply, and was clearly discounted in favour of a continuation of the previous piecemeal approach. $^{62}$

\section{Conclusions}

\footnotetext{
${ }^{61}$ Written reports and proposals by the Programa de Derechos Humanos del Ministerio del Interior, on file with the author, and interviews with Programa personnel in 2014 and 2015, individual identities reserved at interviewees' request.

62 Thus social work services, memorial funds and legal advice to relatives (only) remain with the Programme; victim lists stay definitively closed to new applications, and reparations are paid automatically by the state benefits agency. No state office currently has oversight responsibility or powers over either victim lists or the content of reparations, and survivors have no entitlement to legal or social work support equivalent to that given to relatives.
} 
Public policy efforts in Chile to deal belatedly ${ }^{63}$ with survivors' rights have to date fallen short in both design and execution of the holistic TJ aspirations discussed earlier in this paper. This is particularly true as regards the benchmark of 'reliable, complete, and widely known' truth, constituting a step towards justice. The Valech report of 2004 certainly had public impact, and Commissioners strove to make results both reliable and complete, within the limits of their permitted frame of reference. Those limits were nonetheless significant, particularly regarding definition and accreditation of torture. The completeness of Valech was further limited by the deliberate omission of perpetrator names or clear assignation of institutional responsibility. Levels of public dissemination of Valech's outcomes and implications moreover diminished between iterations and over time. The second iteration had no print version, and failed to notify applicants directly ${ }_{,}^{64}$ while the Commission itself was completely dissolved immediately the list was delivered to the president. Today, it is no easy feat even to trace a complete set of the published reports in a single official repository. ${ }^{65}$

The decoupling of Valech from justice entitlements was explicit and evident, with the attempted legislative prohibition of judicial 'recycling' of information provided to it still largely effective. More generally, justice clearly remains the most restricted dimension of the transitional justice rights matrix regarding torture. The great majority of accountability cases are still brought at private initiative, with most focusing on the dead and disappeared. ${ }^{66}$ When the state, or parts of it, began timidly to move beyond the toleration of private claims to the development of an active prosecution

\footnotetext{
63 'Belated' in regard to the 'timely' justice horizons required by the American Convention on Human Rights; and also when compared to much earlier official action over deaths and disappearances.

${ }^{64}$ Notification was via a now-defunct website. The socioeconomic, geographical, and age profile of applicants made this perhaps the single least appropriate method that could have been chosen, even considering Chile's relatively high levels of urbanisation and connectivity.

65 Online legislative archives contain copies of some relevant legislation. The INDH offers web access to the 2011 list, and advice on entitlements. No governmental site however hosts the 2004-05 and 2011 reports and lists in their entirety.

${ }^{66}$ Around 80 per cent, at a conservative estimate based on Observatorio records at mid-2015.
} 
strategy, ${ }^{67}$ absent victims were similarly prioritised. The relegation of survived violations to a lower tier became if anything more explicit. ${ }^{68} \mathrm{~A}$ notable increase, since 2010 , in survivor-instigated cases for torture has helped to dilute, though not yet to reverse, this trend. ${ }^{69}$

Moving beyond Valech to consider Chile's general approach to TJ, reparations policy is often, and rightly, believed to be one of the more successful dimensions of state transitional justice practice in Chile. As we have seen, 'Rettig measures' were updated then extended to Valech survivors, albeit with some limitations. ${ }^{70}$ Additional and alternative measures had always existed for other categories of victim or survivor. Intergenerational reach, one of the aspirational goals mentioned above, is partially present in various measures, and was introduced to others in $2004 .{ }^{71}$ The integral nature of these and other measures is however more questionable. A reparations study carried out by the Observatorio in 2012 modelled the effects of the different packages on a range of victims/ survivors over time. Measures showed no sign of having been designed to accompany the individual life cycle, nor high levels of synergy one with another.

In the symbolic arena, reparations programmes are almost universally described as 'benefits' rather than entitlements, and are periodically subject to accusations of undue generosity or outright fraud. Their continuity was, as we have seen, thrown into question for survivors during and after Valech. No state entity is currently charged with overseeing reparations or promoting a language of

\footnotetext{
${ }^{67}$ Through, respectively, ex officio investigative orders made by a judicial prosecutor in 2011 and criminal complaints (querellas) made by the Human Rights Programme in its own right after 2009.

${ }^{68}$ A Supreme Court pronouncement in 2010 supported the contention of one specially-designated 'human rights case' magistrate that torture or sexual assault should be investigated as ordinary crimes. Vigorously contested, the disposition has been partly reversed. See Observatorio DDHH, 2012, op. cit.

${ }^{69}$ See TJ-themed chapters of annual human rights reports for 2014 and 2015 by the UDP, op. cit., and the National Human Rights Institute, INDH ( www.indh.cl)

70 Notably, and quite anachronistically, Valech pensions and bonuses are inheritable only by widows (not by widowers) upon decease of the recipient.

${ }^{71}$ When educational scholarships offered as part of Valech entitlements were made transferable to children and grandchildren.
} 
recognition and apology: Correa points out that such neglect diminishes the potential of reparations to restore civic trust. ${ }^{72} \mathrm{~A}$ series of temporally limited truth commissions, none foreseen at the time its predecessor(s) were implemented, have now become the sole entry portals for Chile's major reparations packages. Operational disputes or ambiguities over application deadlines, tax liability, and discontinuation of pensions in cases of suspected fraud, are resolved by non-specialist administrative bodies on an ad hoc basis.

This by-default delegation of operational TJ responsibilities to existing instances not mandated or equipped to carry them out is undoubtedly problematic. So too, however, is the periodic invention of temporary, time-limited instances to deal on a specialised but single-issue basis with truth, or justice, or reparations. Post-hoc adjustments usually ensue, and difficulties often result. Thus the lack of definition of Valech-related reparations until after the event led to unnecessary concern about health entitlements. The shoehorning of 'Rettig cases' - cases of death and disappearance into Valech II trapped the approved cases in the legal framework designed for Valech, meaning files could not be passed to the courts and no agency could work out how to activate reparations to relatives.

Today, the lack of an agency allowed to consider new cases on an ongoing basis means that rights entitlements are potentially being allowed to lapse although the situation of having been victimised, and its effects, does not. Survivors recognised by Valech meanwhile have no access to official legal representation or advice if they wish to pursue justice claims, nor are cases pursued ex officio for torture. ${ }^{73}$ Since there is no administrative route for extending or rescinding victim or survivor status

\footnotetext{
${ }^{72}$ Correa, op.cit.

${ }^{73}$ Limited exceptions have begun to emerge only through the actions of a small number of individual judges, who have begun to open separate investigations if witnesses called in disappearance cases testify that they themselves were tortured. This route is one source of the occasional judicial requests for Valech II case files that are currently being honoured.
} 
in response to case verdicts, judicial branch deliberations which alter the TJ record are simply not assimilated by the state's executive and legislative arms.

This exploration of recent Chilean practice in regard to transitional justice policy accordingly shows little sign of increasing synergy between measures over time, although a larger judicial caseload now exists and a greater quantity of individual truth or reparations measures has been accumulated to the overall 'pile'. This state of affairs suggests both that more should not automatically be mistaken for better, and that policy integration cannot be assumed and, if desired, must instead be consciously designed. The desire in at least some circles to explicitly integrate transitional justice policies is visible in Chile, as in at least two of the other regional examples referred to earlier in this paper (namely Colombia and Brazil). For Chile, as we have seen, the Human Rights Programme, originally a truth instance with a very limited mandate, has since 2014 repeatedly yet unsuccessfully lobbied to become a more holistic transitional justice agency. ${ }^{74}$

Our discussion of the Chilean case nonetheless also suggests that the desirability of such integration of truth, justice and reparation functions and/or instances needs further interrogation, and it is to this question that we now turn. The already enunciated theoretical concerns underpinning this paper include the normative notion of a bundle of inter-related rights which some clearly feel should become the yardstick for state-level design and implementation of TJ measures. In this regard, we may question whether any such bundling of rights is, or could ever be, an unqualified good. The loading of simultaneous truth, justice and reparations responsibilities and expectations onto any particular point of a post-authoritarian or post-conflict process may prove not only impractical but sometimes undesirable. It may, for example, place unrealistic logistical or administrative burdens

\footnotetext{
${ }^{74}$ Sources: written reports and proposals by the Programa de Derechos Humanos del Ministerio del Interior, on file with the author, and interviews with Programa personnel in 2014 and 2015, identities reserved at interviewees' request. See also Observatorio DDHH (2014).
} 
on fragile or resource-poor states even before attention to conflict-related damage is considered. Thus the logistical challenge of constructing a single unified victim register in Peru proved so substantive that plans to postpone all reparations payments until its completion had to be abandoned. Even in Argentina, where the justice dimension of TJ has recently been vigorously pursued, truth and reparations advances have not kept pace.

The simultaneous front-loading of truth, justice and reparations expectations onto the already considerable challenges faced by the ongoing Colombian peace process have meanwhile produced, inter alia, visible pressure on the Inter-American Court to soften the strong pro-prosecution presumption visible in its pre-2012 jurisprudence. ${ }^{75}$ Veto player resistance to TJ may be particularly predictable or visible in regard to justice, but the recent experiences of Peru, El Salvador and others show that truth and reparations measures can equally produce controversy and resistance that at times risks derailing the entire TJ endeavour. ${ }^{76}$ In negatively affecting the credibility of human rights discourse in general, such setbacks can also arguably have deleterious effects on guarantees of nonrepetition. A partial solution perhaps lies in adopting a phased, rather than maximalist, benchmark for measuring states' fulfilment over time of their transitional justice responsibilities. This moves us towards notions of progressive realisation presently more often discussed or admitted in regard to economic, social and cultural rights. Thus while TJ policy may be encouraged or required to address, over time, each of the elements of truth, justice, reparations and guarantees of non-repetition, not every measure need be expected to contribute equally, or even at all, in every element. Enshrining in the norm framework itself the permissibility of phasing and sequencing, allowing states to begin with the measure that generates least internal resistance, might both better map existing practice

\footnotetext{
${ }^{75}$ See Inter-American Court on Human Rights, El Mozote v. El Salvador (2012).

${ }^{76}$ See controversies in Peru over the Ojo que Llora monument, and the subsequent threat by Peru to withdraw from the Inter-American system (Katherine Hite. Politics and the Art of Commemoration (NY: Routledge, 2012)). For El Salvador, civil society completion of a truth commission-mandated victim memorial provoked a right wing municipality to erect a statue to death squad founder Roberto d'Aubuisson.
} 
and encourage reluctant states to start along a TJ road even if they feel unequal to the task of simultaneously meeting a single, ever-growing, agenda of all-or-nothing demands. The notion that even within dimensions, challenges may be more successfully met over time clearly chimes with Lagos's reference to "incremental degrees of truth" (crecientes grados de verdad) in his 2003 No Hay Mañana speech. ${ }^{77}$ While the perils of admitting incrementalism include those of relativising the status of early truthtelling as necessarily incomplete or provisional, the dangers of all-or-nothing maximalism include those of blocking off, as Chile did for so long, the possibility or need for admitting subsequent revision or revelation to the official record.

These issues point to a question raised throughout the paper about the actual effects of synergy, contradiction, or insulation between measures. This paper has taken a largely critical view of attempts to mutually isolate truth and justice, and limit reparations implications, in the design of recent truth measures in Chile. This critique nevertheless proceeds from very specific circumstances: a long-running TJ process, in a country with robust economic capacity demonstrably not threatened by imminent authoritarian regression, with strong rule of law indicators and explicit acceptance of prevailing human rights norms. These norms, as we have seen increasingly prescribe, presuppose or recommend interconnected measures. Chile's reluctance to adopt rights-based language surrounding TJ, and in particular the recent attempt to row back from truth-justice linkages achieved in the previous truth commission, are accordingly particularly difficult to justify. Indeed, although there may well be other scenarios in which the classic truth-or-justice tension still persists, ${ }^{78}$ a regional look at South America, at least, suggests reasonably robust levels of state repudiation of past terror practices combined with strong cross-border civil society mobilisation - facilitated by common languages, pre-transitional solidarity and exile links.

\footnotetext{
77 As cited in Pérotin, op.cit., p 2.

${ }^{78}$ See Alison Bissett, Truth Commissions and Criminal Courts (Cambridge: Cambridge University Press, 2012).
} 
Attempts to seal off judicial consequences to truth, or to corral truth revelations within one set of national borders, appear to be swimming against the tide. State-to-state collaborative agreements were signed in 2013 and 2014 between Chile, Argentina, and Brazil, enshrining commitments to pool and share information about cross-border repression gleaned from dictatorship-era files and truth commission endeavours. The Instituto de Políticas Públicas en Derechos Humanos, IPPDH, a permanent human rights coordination set up by Mercosur countries in 2009, hosts an online archive of documents related to the Cóndor repressive network. Most affected Latin American states, including Chile, have moreover recently introduced access to information or freedom of information laws in recent years. As we have seen above, these can and have been utilised to create or strengthen a presumption of transparency with regard to dictatorship-era archives and/or newly created repositories of testimony. Such tendencies, while not an unqualified good, are a concrete fact, rendering it ever more unlikely that newer TJ endeavours can be controlled by states as tightly as were those carried out early in transition.

Linkages between truth and justice, and in turn, to reparations, nonetheless raise particular dilemmas with regard to overlap and contradiction. As regards overlap, some states have attempted to pre-empt civil claim-making by victims of state harm by retrospectively declaring this to be incompatible with receipt of economic reparations - pensions etc - from administrative programmes. Other states, including Chile, have come to allow both routes, while some clearly hope to discourage either. Since existing norm frameworks are largely silent on which mode of delivery of the right to reparations is to be 'preferred', all of these alternatives except for the last are arguably legitimate. However, the increasing emphasis on victim-centredness which surrounds reparations discussions is potentially both contradictory and disruptive of synergy, whichever mode(s) of reparation are in operation. The internally contradictory aspect arises because victimcentredness, usually recommended from a desire to augment overall takeup, makes a case for 
needs-based, tailor-made, and/or participatory models of reparation. Transparency, fiscal responsibility, and adequate entry filters to minimise fraud or error in reparation nonetheless limit the extent to which programmes can proceed via a victim-centred presumption of veracity regarding individual testimony. Indeed, Zalaquett implicitly criticises the "flexible" criteria applied to preValech reparations programmes, based, he says, on giving "the benefit of the doubt" (Zalaquett, op. cit. p. 61 , my translation). ${ }^{79}$

Tying reparations access instead to truth commission outcomes or the results of judicial processes is rarely, however, a satisfactory solution to this difficulty. In a trial setting, harm that is to be adduced as evidence against a defendant will be subject to stringent evidentiary standards that far exceed those which are appropriate as a threshold for reparations. Thus a person may be unable to prove in court that particular, named individuals can or should be held criminally or civilly liable for harm caused to him or her, even while it is quite evident that the harm was indeed caused, and that the state was responsible. Truth commission may develop, as the Salvadoran one did, sui generis taxonomies for classifying incidents as accepted fact, likely, or unproven; but such scales are unsuited to judicial or reparatory purposes. Valech suffered similar limitations: the decision not to classify a case was often interpreted by survivors as a slight on their honesty rather than a sign of a deficient mandate. ${ }^{80}$

Yoking together official truth acknowledgement with reparations entitlements meanwhile in effect adds economic connotations to inclusion on victim lists, which inescapably alters the nature and purpose of truthseeking. It is also particularly likely, in symmetrical or quasi-symmetrical conflicts,

\footnotetext{
${ }^{79}$ See, for a general discussion, C. Waterhouse, 'The Good, the Bad, and the Ugly: Moral Agency and the Role of Victims in Reparations Programs'. University of Pennsy/vania Journal of International Law, 31:1 (2009), pp. 257-94.

${ }^{80}$ See Observatorio DDHH report on Valech methods, op. cit. Based also on the author's experience of offering workshops on Valech II outcomes, to Santiago-based survivors' groups and to a national association of former child detainees, in 2012.
} 
to add a new edge to debates about state versus nonstate, individual versus collective, attribution of responsibilities. There is scarce evidence to date that these complexities have been coherently addressed by individual state initiatives, as we have seen. Nor are they commonly dealt with in the core texts of regional and international norm sets, as is perhaps to be expected. Nonetheless, since both domestic practice and Inter-American system resolutions and verdicts increasingly straddle multiple dimensions of TJ, the underlying suppositions about synergy that underpin such approaches may repay closer study.

12,034 